\title{
LAJU PERTUMBUHAN DAN KEPADATAN MIKROALGA Dunaliella sp. PADA PEMBERIAN TIMBAL ASETAT DENGAN KONSENTRASI YANG BERBEDA
}

\author{
Growth Rate and Density of Microalgae Dunaliella sp. Treated With Lead \\ Acetate at Different Concentrations
}
Fitly Tewal*, Kurniati Kemer, Joice R.T.S.L. Rimper, Desy M.H. Mantiri, Wilmy E. Pelle, Joppy D. Mudeng.
Program Studi IImu Kelautan Fakultas Perikanan dan Ilmu Keluatan Universitas
Sam Ratulangi
*e-mail: fittewal@gmail.com

\begin{abstract}
Microalgae are organisms that contain chlorophyll and other pigments so they can carry out photosynthesis. Microalgae are widespread in nature and can be found in any environment exposed to sunlight. Microalgae are micro-sized biota with a diameter of less than $2 \mu \mathrm{m}$. The benefits of microalgae for other living things, especially humans, are numerous, including as a source of food and ingredients in the manufacture of medicines. Dunaliella sp. is a group of green algae that contains protein, fat and carbohydrates as a good source of food. Growth rate and density of microalgae Dunaliella sp. and the effect of lead acetate with different concentrations was observed using a microscope, starting from the lag phase, the logarithmic phase, the stationary phase and the declination phase. Dunaliella sp. Experiencing an exponential phase in the observation before treatment, namely on the 9th day and then doing the treatment. Treatment with lead acetate with concentrations of $10 \mathrm{ppm}, 50 \mathrm{ppm}$ and $80 \mathrm{ppm}$ is very influential in the growth of microalgae. The result is that lead acetate contains toxins that can kill microalgae cells in both low and high concentrations.
\end{abstract}

Keywords: Microalgae, Dunaliella sp., Lead Acetate, Concentration.

Mikroalga merupakan organisme yang mengandung klorofil serta pigmen-pigmen lain sehingga dapat melakukan fotosintesis. Mikroalga tersebar luas di alam dan dapat dijumpai di semua lingkungan yang terkena sinar matahari. Mikroalga adalah biota yang berukuran mikro dengan ukuran diameternya kurang dari $2 \mu \mathrm{m}$. Manfaat mikroalga untuk mahluk hidup lainya, terutama manusia sangat banyak, diantaranya sebagai sumber makanan dan bahan dalam pembuatan obat-obatan. Dunaliella sp. merupakan kelompok alga hijau yang mempunyai kandungan protein, lemak, dan karbohidrat sebagai sumber pangan yang baik. Laju pertumbuhan dan kepadatan mikroalga Dunaliella sp. dan pengaruh pemberian timbal asetat dengan konsentrasi yang berbeda diamati menggunakan mikroskop, mulai dari fase lag, fase logaritmik, fase stasioner dan fase deklinasi. Dunaliella sp. mengalami fase eksponesial pada pengamatan sebelum perlakuan yaitu di hari ke 9 dan kemudian dilakukan perlakuan. Perlakuan dengan pemberian timbal asetat dengan konsentrasi 10 ppm, 50 ppm dan 80 ppm sangat berpengaruh dalam pertumbuhan mikroalga. Diakibatkan timbal asetat mengadung racun yang bisa membunuh sel mikroalga baik dengan konsentrasi yang rendah maupun konsentrasi yang tinggi.

Kata kunci: Mikroalga, Dunaliella sp., Timbal Asetat, Konsentrasi. 


\section{PENDAHULUAN}

Dunaliella sp. memiliki habitat di perairan laut dan sering ditemukan di danau, rawa serta parit-parit dekat perairan laut (Ben-Amotz, 2004). Salinitas yang optimal untuk menunjang pertumbuhan yaitu 18-22 ppt (Isnansetyo dan Kurniastuty, 1995). Dunaliella sp. merupakan fitoplankton yang memiliki sifat halofilik yang artinya mampu bertahan hidup dalam lingkungan yang memiliki kadar garam tinggi (Smith et al., 2010). Dunaliella sp. juga bersifat eurythermal atau dapat bertahan terhadap kisaran suhu yang lebar. Alga ini dapat bertahan pada suhu rendah hingga di bawah titik beku sampai suhu tinggi yaitu $40^{\circ} \mathrm{C}$ (Isnansetyo dan Kurniastuty, 1995).

Salah satu parameter lingkungan yang menunjang pertumbuhan Dunaliella sp. adalah intensitas cahaya, salinitas, $\mathrm{pH}$ dan suhu. Cahaya menjadi salah satu faktor pembatas bagi keberlangsungan hidup Dunaliella sp. Cahaya yang bersumber dari energi matahari dibutuhkan oleh Dunaliella sp. dalam proses fotosintesis, laju fotosintesis akan meningkat bila intensitas cahaya meningkat dan menurun bila intensitas cahaya berkurang (Isnansetyo dan Kurniastuty, 1995).

Lavens and Sorgeloos (1996), menjelaskan bahwa pertumbuhan fitoplankton dibagi menjadi lima fase yaitu :

1. Fase Lag

Pertumbuhan

fitoplankton pada fase ini dikaitkan dengan adaptasi fisiologis metabolisme sel pertumbuhan fitoplankton, seperti peningkatan kadar enzim dan metabolit yang terlibat dalam pembelahan sel dan fiksasi karbon.

\section{Fase Eksponensial}

Fase eksponensial
ditandai dengan sel
fitoplankton telah mengalami
pembelahan sel dengan laju
pertumbuhan relatif tetap.
Pertumbuhan fitoplankton
dapat maksimal tergantung
pada spesies alga, nutrien,
cahaya dan temperatur.

3. Fase Penurunan Laju Pertumbuhan

Pertumbuhan sel mulai melambat ketika nutrisi, cahaya, $\mathrm{pH}, \mathrm{CO}_{2}$ atau faktor kimia dan fisika lain mulai membatasi pertumbuhan.

4. Fase Stasioner

Fase stasioner ditandai dengan kematian fitoplankton hampir sama dengan laju pertumbuhannya sehingga kepadatan fitoplankton pada fase ini relatif konstan. Berdasarkan penelitian yang dilakukan oleh Fazeli et al. (2006), pembentukan $\beta$ karoten pada genus Dunaliella lebih tinggi pada fase stasioner dari pada fase eksponensial.

5. Fase Kematian

Fase kematian ditandai dengan kondisi kualitas air menurun dan kandungan nutrisi rendah sehingga kepadatan sel menurun dengan cepat karena laju kematian fitoplankton lebih tinggi daripada laju pertumbuhannya sampai kultur berakhir.

Mikroalga Dunaliella sp. mudah terkontaminasi dengan bahan pencemar seperti bahan logam berat yakni timbal $(\mathrm{Pb})$ yang masuk ke perairan, semakin tinggi kadar logam berat timbal $(\mathrm{Pb})$ dalam perairan, bersifat toksik terhadap pertumbuhan mikroalga Dunaliella sp. (Mantiri et al, 2001)

Logam berat mempunyai sifat yang mudah mengikat bahan 
organik dan mengendap di dasar perairan dan bersatu dengan sedimen sehingga kadar logam berat dalam sedimen lebih tinggi dibanding dalam air. Timbal $(\mathrm{Pb})$ merupakan salah satu bahan pencemar yang termasuk dalam kategori golongan logam berat. Timbal dapat mencemari lingkungan perairan, selain itu juga mempengaruhi kehidupan organisme yang hidup di dalamnya (Darmono 1995). Dalam penelitian ini dilaksanakan untuk mengetahui laju pertumbuhan dan kepadatan mikroalga tanpa pemberian logam berat dan dengan pemberian logam berat.

\section{METODE PENELITIAN}

Penelitian ini untuk mengamati proses laju pertumbuhan dan kepadatan mikroalga Dunaliella sp. yang dikultur dalam laboratorium Teknologi Akuakultur dengan suhu ruangan $25^{\circ} \mathrm{C}$ dan penyinaran lampu 48 watt, mulai dari fase awal pertumbuhan sampai fase akhir. Pengamatan dengan melihat kepadatan dan laju pertumbuhan sel dilakukan setiap hari dengan mikroskop kemudian saat pemberian perlakuan dengan timbal asetat dan sampai pada proses akhir yaitu kematian pada mikroalga.

Air laut yang menjadi media untuk mikroalga diambil di perairan teluk Manado yaitu di pantai Boboca Malalayang. Perairan di daerah ini masih relatif bersih sehingga memungkinkan untuk digunakan. Air laut yang diambil kemudian dibawa ke Laboratorium untuk tahap penyaringan.

Penyaringan air laut dilakukan untuk membersihkan atau memisahkan kotoran-kotoran yang susah dibersikan dengan manual sehingga mengunakan alat bantu laboratorium berupa vakum yang dilengkapi dengan kertas saring, corong buchner dan labu Buchner. Penyaringan air laut ini dilakukan di Laboratorium Kesehatan Ikan,
Air laut yang sudah disaring kemudian dimasukan ke dalam Erlenmeyer yang berukuran $1000 \mathrm{ml}$, dan dibungkus dengan alluminium foil untuk proses sterilisasi menggunakan autoclave dengan suhu $121^{\circ} \mathrm{C}$ selama 15 menit. Sterilisasi air laut dilakukan di Laboratorium Biologi Molekuler \& Famasitika Laut.

Media kultur yang digunakan adalah labu ukur yang memiliki takaran $250 \mathrm{ml}$ dan dimasukan air laut yang sudah disterilkan sebanyak $200 \mathrm{ml}$. Kemudian media kultur dimasukan nutrien yaitu media walne sebanyak $200 \mu l$ menggunakan mikropipet 1000 $\mu \mathrm{l}$. Labu ukur yang sudah terisi sampel dan nutrien kemudian disimpan dilemari kultur Laboratorium Teknologi Akuakultur dengan suhu ruangan 25 ${ }^{\circ} \mathrm{C}$ dan penyinaran lampu 48 watt. Sampel mikroalga Dunaliella sp. diperoleh dari stok atau hasil kultur laboratorium Teknologi Akuakultur Universitas Sam Ratulangi Manado. Menghitung kepadatan mikroalga Dunaliella sp. dilakukan dengan menggunakan mikroskop dan hemositometer pada pembesaran 40x. Sampel dilakukan 5 kali pengulangan dan melihat jumlah kepadatan sel yang terbanyak. Menghitung kepadatan dengan hemositometer adalah dengan melihat sel yang tersuspensi kedalam kamar hitung atau kotak kecil pada hemositometer. Pengamatan ini dilaksanakan selama 9 hari awal kultur dan 15 hari pengamatan dengan pemberian timbal asetat dan diamati setiap hari pada jam yang sama yaitu pukul 12.00 siang. Pengamatan ini dilaksanakan di Laboratorium Kesehatan Ikan, Lingkungan dan Toksikologi.

Pemberian timbal asetat dilakukan dimana mikroalga berada pada fase eksponensial atau fase dimana laju pertumbuhan dan kepadatan mikroalga relatif tetap. Perlakuan dilakukan dengan membagi sampel atau media kultur menjadi 4 labu, dimana 3 labu untuk pemberian timbal asetat dan 1 labu sebagai 
kontrol. Dari 3 labu yang diberi timbal asetat masing-masing berkonsentrasi 10 ppm, 50 ppm dan 80 ppm. Sampel yang sudah diberi perlakuan kemudian dimasukan kembali ke dalam lemari kultur dan akan diamati kembali hingga 15 hari dengan waktu dan pengulangan yang sama. Pemberian perlakuan dilaksanakan di Laboratorium Teknologi Akuakultur sedangkan untuk menimbang timbal asetat menggunakan timbangan analitik di Laboratorium Kesehatan Ikan dan Toksikologi.

\section{Analisis Data}

Kelimpahan organisme dapat disajikan dengan mengukur kepadatan (Krebs, 1989). Kepadatan adalah besarnya populasi dalam suatu unit ruang yang dinyatakan dalam jumlah individu dari populasi dalam suatu unit (Odum, 1971).

Kepadatan sel mikroalga Dunaliella sp. dihitung menggunakan haemocytometer, ditemukan dalam 16 kotak kecil pada haemocytometer jumlah sel $\times 10^{4} \mathrm{sel} / \mathrm{ml}$. Tebal dari ruang hitung ini adalah $0,1 \mathrm{~mm}$. Sel mikroalga yang tersuspensi akan memenuhi volume ruang hitung tersebut sehingga jumlah mikroalga per satuan volume dapat diketahui.

Menurut Anita Padang (2018) Analisis data untuk mengetahui kepadatan dapat dihitung dengan menggunakan rumus:

$$
\mathrm{N} \times 10^{4} \mathrm{sel} / \mathrm{ml}
$$

Dimana :

$\mathrm{N}=$ Jumlah rata-rata sel yang terdapat pada kotak bujur sangkar

$\mathrm{X} 10^{4}=$ Jumlah kepadatan sel sebenarnya pada $1 \mathrm{ml}$ media atau air

$\mathrm{Sel} / \mathrm{ml}=$ Satuan kepadatan fitoplankton

Setelah menghitung kepadatan

terbanyak dalam 1 kotak sedang dengan 16 kotak kecil, kemudian hasil dicatat, data yang diperoleh akan dhitung dalam rumus kemudian diolah dengan Microsoft excel untuk mengetahui hasil dan grafik yang diperoleh.

\section{HASIL DAN PEMBAHASAN}

Pengamatan awal pertumbuhan mikroalga Dunaliella sp. dilakukan dengan cara menghitung kepadatan mikroalga sampai pada fase eksponensial yaitu di hari ke 9 kemudian dilakukan perlakuan dengan membagi menjadi 4 wadah, dimana 3 wadah untuk pemberian senyawa timbal asetat dan 1 wadah untuk kontrol. Kepadatan sel mikroalga Dunaliella sp. dihitung menggunakan haemocytometer yang diamati dengan mikroskop cahaya dengan pembesaran $40 x$.

\section{Pengamatan Awal Kultur}

Berdasarkan hasil pengamatan yang dilakukan selama 24 hari, yaitu 9 hari pengamatan sampai pada fase eksponesial sebelum perlakuan dengan melihat kepadatan dari sampel mikroalga Dunaliella sp. dengan 5 kali pengulangan sehingga didapat hasil rata-rata seperti pada grafik.

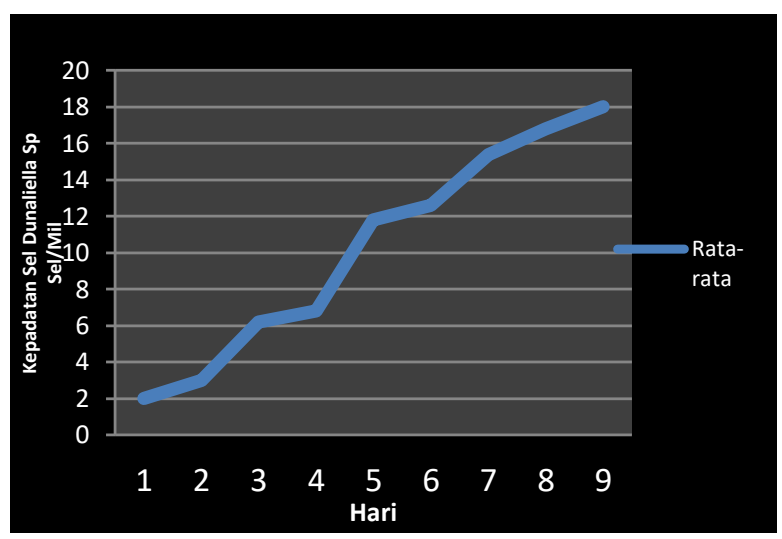

\section{Gambar 1}

Kepadatan sel Dunaliella sp. (sel/mil)

Berdasarkan grafik di atas bahwa kepadatan sel dari hari ke 1 sampai dengan hari ke 4 menunjukan sel yang beradaptasi atau mengalami metabolisme sebelum terjadinya pembelahan. Pada hari ke 5 sel mulai mengalami pembelahan dengan 
memanfaatkan nutrient yang diberikan dalam wadah kultur sehingga perlahan-lahan pertumbuhan sel mulai meningkat hingga dihari ke 8 sampai hari ke 9 dimana fase eksponensial terjadi dan kemudian akan dilanjutkan dengan pemberian perlakuan. Dalam penelitian yang dilakukan Balaira (2017) mengatakan bahwa tahap eksponensial berada pada hari ke $8 \mathrm{di}$ ketahui pada wadah kontrol. Pada hari ke 9 alga sudah mengalami penurunan jumlah sel, sehingga dapat simpulkan rata-rata pertumbuhan mikroalga Dunaliella sp dalam kultur terjadi fase eksponesial pada hari ke 8 ataupun 9. Bertambahnya sel dalam kultur dapat diawali dengan berubahnya warna pada wadah kultur.

\section{Pemberian Perlakuan}

Perlakuan dilakukan dengan cara sampel Dunaliella sp. atau wadah kultur yang sudah diamati sebelumnya selama 9 hari, dibagi menjadi 4 wadah, dimana 1 wadah untuk kontrol dan 3 wadah yang mengandung timbal asetat dengan konsentrasi yang berbeda-beda yaitu $10 \%(0,006 \mathrm{mg})$, $50 \%(0,01 \mathrm{mg})$ dan $80 \%(0,02 \mathrm{mg})$. Pada pengamatan saat perlakuan dengan timbal asetat ini dilakukan selama 15 hari.

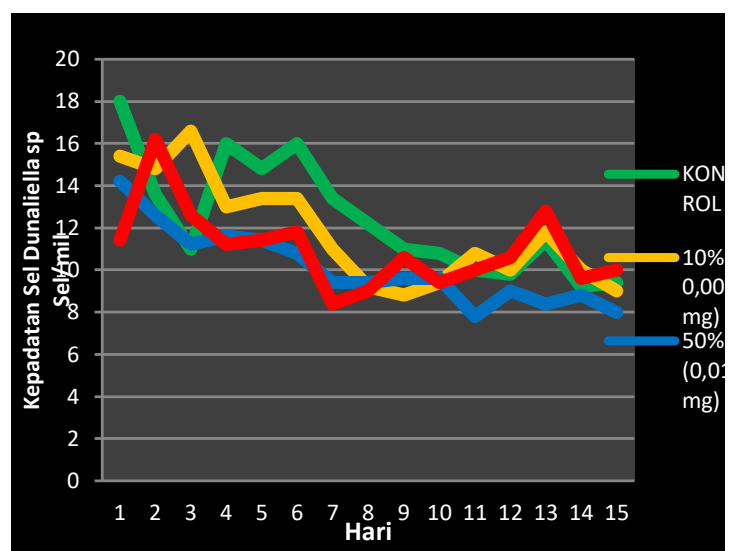

Gambar 1

Grafik Pertumbuhan sel Dunaliella sp. saat pemberian perlakuan

\section{Kontrol}

Pengamatan pada wadah kontrol menunjukkan laju pertumbuhan mikroalga Dunaliella sp. bervariasi seperti pertumbuhan mikrolaga pada umumnya. Sel mikroalga Dunaliella sp. mengalami pertumbuhan yang cukup besar karena nutrient yang masih tersedia dalam wadah kultur dan sel dapat bereproduksi dengan cepat dan menghasilkan pertumbuhan serta kepadatan yang relatif stabil sampai pada akhir pengamatan.

Kepadatan mikroalga pada hari
pertama setelah perlakuan menunjukan jumlah kepadatan sel yang cukup baik dan pada hari ke 3 sampai dengan hari ke 7 pertumbuhan sel mikroalga Dunaliella sp. cukup besar, dan pada hari ke 8 sampai dengan hari ke 15 mikroalga tidak mengalami kematian yang besar melainkan menunjukkan pertumbuhan sel yang perlahan-lahan dapat dikatakan stabil.

\section{Timbal Asetat 10\%}

Dari hasil pengamatan yang dilakukan pada pemberian timbal asetat dengan konsentrasi 10\% $(0,006)$ menunjukan pertumbuhan mikroalga meengalami penurunan yang cukup besar. Jumlah kematian sel dapat dilihat pada pengamatan dengan hemositometer dan menurunnya kualitas air pada wadah kultur

\section{Timbal Asetat 50\%}

Untuk pemberian timbal asetat pada wadah ketiga dengan konsentrasi $50 \%(0,01)$, dapat dilihat dengan konsentrasi yang cukup banyak, sel mengalami penurunan laju pertumbuhan yang cukup. Pada pengamatan dengan mikroskop dan hemositometer. Kepadatan sel berkurang berbeda dengan konsentrasi $10 \%$.

\section{Timbal Asetat $80 \%$}

Pada pemberian timbal asetat yang cukup besar yaitu dengan konsentrasi $80 \%(0,02)$ pada awal 
pemberian timbal sel mengalami pertumbuhan yang cukup banyak hampir sama dengan pada pemberian dengan konsentrasi $50 \%$, sehingga pada konsentrasi ini fase lag dan fase eksponesial terjadi pada hari ke 2 dan hari ke 3 , dimana penurunan laju pertumbuhan dan fase stasioner mulai terjadi pada hari ke 4 sampai pada hari ke 10. Pertumbuhan sel pada hari selanjutnya menunjukkan pertumbuhan yang stabil karena kepadatan sel bertambah diakibatkan sel yang mati dimanfaatkan oleh sel yang hidup sebagai nutrient untuk pertumbuhan. Pada hari terakhir pengamatan sel mulai mengalami kematian diakibatkan konsentrasi yang cukup besar ini karena jumlah kematian cukup banyak dari pada jumlah sel yang bereproduksi.

Berdasarkan grafik diatas dapat dilihat bahwa kepadatan sel Dunaliella sp. mengikuti pola pertumbuhan kultur fitoplankton secara umum yaitu pada fase lag, fase eksponensial, fase stasioner, dan fase kematian. Namun pada hari terakhir pengamatan jumlah sel hanya mengalami penurunan kepadatan, sehingga penurunan kepadatan ini dapat menjadi fase terakhir dari pertumbuhan sel Dunaliella sp.

Kepadatan mikroalga merupakan salah satu parameter pertumbuhan yang dapat digunakan sebagai acuan untuk mengetahui apakah mikroalga tersebut tumbuh atau tidak. Pertumbuhan mikroalga terdiri dari fase lag, fase ekponesial, fase penurunan laju pertumbuhan, fase stasioner dan fase kematian

Pada awal pengamatan, wadah sampel mikroalga Dunaliella sp. dengan 5 kali pengulangan dan diamati selama 9 hari serta perlakuan selama 15 hari mikroalga mengalami fase lag pada hari ke-1 dimana pada fase ini mikrolaga masih dalam tahap adaptasi sebagai upaya penyesuaian diri dari perubahan kondisi lingkungan media yang baru. Menurut Isnansetyo dan Kurniastuti (1995) bahwa fase lag terjadi kurang dari 24 jam setelah penambahan inokulan kedalamn media kultur. Pada fase lag ukuran sel akan meningkat serta mengalami metabolisme sel tetapi belum mengalami pembelahan.

Pada pengamatan awal tanpa perlakuan, dimana pada hari ke 1 sampai pada hari 4 terjadi fase lag atau fase dimana mikroalga beradaptasi dengan lingkungannya. Dari data yang diperoleh pola pertumbuhan dari mikroalga Dunaliella sp. mengikuti pola pertumbuhan mikroalga pada umumnya, sehingga pada hari ke 5 sampai hari ke 8 pertumbuhan sel relatif baik hingga pada hari ke 9 yang merupakan fase dimana sel dengan laju pertumbuhan dan kepadatan relatif tinggi atau fase eksponensial.

Setelah sampai pada fase eksponensial dilakukan perlakuan dengan pembagian wadah dimana wadah 1 sebagai kontrol dan 3 wadah lainya diberi timbal asetat untuk melihat laju pertumbuhan dan kepadatan dari masing-masing konsentrasi yang diberikan.

Pada wadah kontrol fase eksponesial terjadi pada awal pengamatan bersamaan dengan perlakuan yaitu pada hari pertama pengamatan, setelah itu terjadi fase dimana laju pertumbuhan sel mulai menurun akibat beberapa faktor baik kekurangan nutrien, cahaya ataupun faktor kimia dan fisika lainnya. Pertumbuhan pada wadah ini mengalami fase stasioner sampai pada fase kematian, namun pada fase kematian sel tidak seluruhnya habis hingga pada akhir pengamatan, diakibatkan nutrien masih tersedia pada wadah.

Pada wadah yang diberikan timbal asetat dengan konsentrasi $10 \%$ $(0,006)$ memberikan pengaruh pada pertumbuhan dan kepadatan sel Dunaliella sp. dimana pada hari ke 1 sampai hari ke 6 pertumbuhan sel cukup stabil dengan jumlah kematian yang sedikit, namun ketika masuk pada hari 7 sampai pada hari ke 13 laju 
pertumbuhan mulai berkurang dan stabil atau berada pada fase stasioner, ketika masuk pada hari ke 14 dan 15 setelah diamati laju pertumbuhan mulai menurun diakibatkan sel kekurangan nutrient dan pengaruh timbal asetat yang bersifat racun. Pada wadah kontrol pengamatan tidak dilakukan hingga mikrolga Dunaliella sp. benar-benar mati atau habis.

Untuk wadah dengan konsentrasi $50 \%(0,01)$ terjadi fase penurunan laju pertumbuhan pada hari ke 1 sampai pada hari ke 5 dimana jumlah kematian masih relatif sedikit kemudian pada hari ke 6 sampai hari 12 kepadatan mikrolga dapat dikatakan stabil atau berada pada fase stasioner, kemudian di hari ke 13 sampai hari ke 15 pengamatan terakhir mikroalga berada pada fase kematian akibat pengaruh timbal asetat yang cukup banyak.

Wadah terakhir dengan pemberian timbal asetat dengan konsetrasi yang cukup banyak yaitu $80 \%(0,02)$, mikrolaga mengalami pertumbuhan yang tidak stabil, dimana pada hari ke 7 sampai hari ke 12 mikroalga mengalami penurunan kepadatan perlahan-lahan, dan naik lagi pada hari ke 12 dan 13, sehingga dari hasil pengamatan pertumbuhan mikroalga tidak stabil, namun pada hari ke 14 dan 15 kematian mikroalga relatif banyak. Ini menunjukan bahwa pengaruh dari timbal asetat dengan konsentrasi yang tinggi dapat mamatikan sel Mikroalga Dunaliella sp. secara perlahan.

\section{KESIMPULAN}

Dari hasil penelitian ini dapat disimpulkan bahwa

1. Laju pertumbuhan mikroalga Dunaliella sp. menunjukan pola pertumbuhan mikroalga pada umumnya, dimana pertumbuhan terjadi fase lag dan fase eksponensial dimana puncak pertumbuhan mikroalga yang kemudian dilakukan perlakuan.
2. Perlakuan timbal asetat sangat berpengaruh dalam pertumbuhan mikroalga Dunaliella sp. karena timbal asetat mengadung racun yang bisa membunuh sel mikroalga baik dengan konsentrasi yang rendah maupun konsentrasi yang tinggi.

3. Pertumbuhan sel Dunailiella sp. dengan pemberian timbal asetat menunjukan pertumbuhan yang tidak stabil, dimana timbal asetat dengan konsentrasi 10 ppm, 50 ppm, dan 80 ppm menunjukan pola pertumbuhan yang unik, dimana masing-masing pertumbuhan hampir sama. Terutama pada konsentasi yang lebih tinggi yaitu $80 \mathrm{ppm}$, pola pertumbuhan dan kepadatan hampir sama dengan konsetrasi 10 ppm dan 50 ppm, apalagi dengan wadah kontrol.

\section{DAFTAR PUSTAKA}

Anita Padang, Abdurahim Lestaluhu, Rosida Siding, 2018. Pertumbuhan Fitoplankton Dunaliella $\mathrm{sp}$ dengan Cahaya Berbeda pada Skala Laboratorium. Jurnal Agribisnis Perikanan (E-ISSN 25988298/P-ISSN 1979-6072). Dipublikasi : 2 Mei 2018

Ben-amotz, A 2004. Industrial Production of Microlgal CellMass and Secondary ProductsMajor Industrial Species, Hadbook of Microalgal Culture : Biotehcnology and Applied Phycology Edited by Amos Richmond Copyright. pp. 258292 
Darmono, 1995, Logam Dalam Sistem Biologi Makhluk hidup, 111, 131-134, Universitas Indonesia Pers.

Fazeli, M. R,. H. Tofighi,. N Samadi and $\mathrm{H}$. Jamalifar. 2006. Effects of Salinity on B-Carotene Production by Dunalilella tertiolecta DCCBC26 Isolated from The Urmia Salt Lake, North of Iran. 97:2453-2456

Greisela Y. Ballaria, G.Y., Kemer, K., Mantiri, D.M.H., (2017). Pemisahan Pigmen Pada Mikroalga Dunaliella salina Yang Telah Diberi Senyawa Timbal Asetat. Jurnal Pesisir dan Laut Tropis, Vol 1(1), 4149.

Isnansetyo, A dan Kurniastuty 1995. Teknik Kultur Phytoplankton dan Zooplankton. Pakan Alami untuk Pembenihan Organisme Laut. Yogyakarta: Kanisius.

Joshep Tamalonggehe., Kurniati Kemer, Darus Sa'adah J. Paransa1, Desy M.H. Mantiri1, Nickson J. Kawung, Suzanne L. Undap., (2020). Efek Senyawa Timbal Asetat Terhadap Pertumbuhan Dan Kandungan Pigmen Klorofil Mikroalga Dunaliella sp. Jurnal Pesisir dan Laut Tropis, Vol $8(2)$

Kemer K., Mantiri D. M. H., Rompas R. M., Rimper J. R., Margyaningsih N. I., 2020 Transmission electron microscope analysis upon growth of lead acetate treated microalga, Dunaliella sp. AACL Bioflux 13(2):849-856.

Krebs, C.J. 1989. Ecologycal Methodology. Harper Collins Publisher. New York. 649p
Lavens, P dan P. Sorgeloos (eds). 1996. Manual on the production and Use of live Food for Acuaculture. FAO Fisheries Technical Paper. No. 361. Rome: Food and Agriculture Organization of the United Nations.

Mantiri D.M.H., Inkiriwang, .P. A., Wowor P. 2001. Pengaruh Logam Tembaga Terhadap Pertumbuhan dan Kandungan Pigmen Dunaliella sp. Jurnal Fakultas Perikanan Vol 2(4): 52-55.

Odum, E.P., 1971 Fundamental of Ecology. W.B. Sounders Company, Philadelphia. 